\title{
Usefulness of three probes in typing isolates of methicillin- resistant Staphylococcus aureus (MRSA)
}

\author{
C. MONZON-MORENO, SYLVIE AUBERT, ANNE MORVAN and NÉVINE EL SOLH*
}

Laboratoire des Staphylocoques et des Streptocoques, National Reference Center for Staphylococci, Institut Pasteur, 25 Rue du Dr Roux, 75724 Paris Cedex 15, France

\begin{abstract}
Summary. Fifty-nine epidemiologically unrelated methicillin-resistant Staphylococcus aureus (MRSA) isolates from different geographical areas and 23 phage-type 77 MRSA isolates from France were investigated. Cellular DNA, digested with restriction endonucleases EcoRI or HindIII, was probed with plasmids carrying the gene encoding $16 \mathrm{~S}$ rRNA (pBA2), the gene $a a c \mathrm{~A}-a p h \mathrm{D}$ (pSF815A) and the gene $a a c \mathrm{~A}-a p h \mathrm{D}$ plus part of IS256 (pIP1307). When probed with pBA2, most of the unrelated isolates displayed the same hybridisation pattern. A greater diversity in patterns was detected in gentamicin-resistant strains with the two other probes. The most accurate fingerprinting of these isolates was obtained with the probe pIP1307. Moreover, this probe appeared to be useful for tracing the phage-type 77 epidemic MRSA isolates widespread in French hospitals.
\end{abstract}

\section{Introduction}

Outbreaks of nosocomial infections attributable to methicillin-resistant Staphylococcus aureus (MRSA) strains have been reported worldwide. ${ }^{1-14}$ Epidemiological assessment of each outbreak involves the typing of strains. Molecular methods for typing MRSA strains include analysis of plasmid content, ${ }^{15-22}$ cellular DNA restriction endonuclease patterns, ${ }^{23-27}$ electrophoretic profiles of the cellular proteins, ${ }^{28-31}$ immunoblotting profiles ${ }^{23,24,29,32}$ and esterase electrophoretic profiles. ${ }^{33}$ The numerous reports describing these methods reflect the limits of the more traditional typing methods, mainly consisting of drugresistance phenotyping, $6,14,34$ phage-typing ${ }^{21,35,36}$ and serotyping. ${ }^{37-39}$ These limits were encountered particularly in typing the MRSA strains isolated in France that were found to have many properties in common. ${ }^{16,33,34,40,41}$

Since December 1984, phage-type 77 MRSA strains have been isolated in numerous French hospitals. Additional typing methods are required to confirm that these isolates are closely related because the number of phage reactions was limited and because some of the reactions were weak and not reproducible. Among the numerous approaches that have been proposed to differentiate closely related prokaryotic organisms, cellular DNA analysis was chosen for the present analysis because, by this method, the potential pitfalls associated with the variable expression of phenotype can be avoided.

The aim of this study was to evaluate the usefulness of three DNA probes for typing MRSA strains and

Received 25 Sep. 1990; accepted 7 Dec. 1990.

* Correspondence should be sent to Dr N. El Solh. for tracing the gentamicin-resistant phage-type 77 MRSA isolates that are widespread in French hospitals. Epidemiologically unrelated MRSA isolates, as well as phage-type 77 French MRSA isolates, were probed with three plasmids, $\mathrm{pBA} 2^{42}, \mathrm{pSF} 815 \mathrm{~A}^{43}$ and pIP $1307^{44}$ carrying, respectively, the Bacillus subtilis gene encoding 16S rRNA, the aacA-aphD gene encoding kanamycin-gentamicin resistance and isolated from a strain of Enterococcus faecalis, and the gene $a a c \mathrm{~A}-a p h \mathrm{D}$ and a $0 \cdot 3-\mathrm{kb}$ fraction of IS256 isolated from a strain of $S$. aureus.

\section{Materials and methods}

\section{Bacterial strains and plasmids}

One hundred and two clinical isolates of $S$. aureus were studied: (i) 59 MRSA isolates from different geographical areas (22 isolates from 18 different locations in the USA and Canada, 13 isolates from France and 24 isolates from 12 other European countries); (ii) 23 MRSA isolates with similar phagetypes isolated over a 3-year period (1984-1987) in seven French hospitals, of which five were located in Paris (table I); and (iii) 20 epidemiologically unrelated methicillin-susceptible $S$. aureus (MSSA) strains consisting of 17 isolates from hospitals located in several French cities and strains ATCC12600, ATCC65380 (American Type Culture Collection) and RN450. ${ }^{45}$

The E. coli strains used were $\mathrm{HVC} 45,{ }^{46} \mathrm{SF} 8,{ }^{42}$ SF815A ${ }^{43}$ and $\mathrm{BM} 3887,{ }^{44}$ harbouring plasmids pBR322, ${ }^{47}$ pBA2, ${ }^{42}$ pSF815A ${ }^{43}$ and pIP1307, ${ }^{44}$ respectively. Plasmid pBA2 contains a $2 \cdot 3-\mathrm{kb} B$. subtilis DNA fragment encoding 16S rRNA inserted in the HindIII site of plasmid pBR322. Plasmid pSF815A consists of plasmid pUC8 plus a $1 \cdot 5-\mathrm{kb}$ AluI insert 
carrying the Ent. faecalis gene aacA-aphD specifying the bifunctional resistance enzyme AAC6'-APH2" that inactivates gentamicin, kanamycin and related aminoglycosides. Plasmid pIP1307 consists of plasmid pBR322 with a $2 \cdot 1-\mathrm{kb}$ HindIII insert isolated from the cellular DNA of a French MRSA isolate and carrying the gene aacA-aphD. This insert was shown to be derived, by deletion, from the $2 \cdot 5-\mathrm{kb}$ HindIII internal fragment of transposon Tn 4001 and to contain, in addition to the gene $a a c \mathrm{~A}-a p h \mathrm{D}$, a 297-bp sequence from strain IS256 (this study).

\section{Susceptibility to antimicrobial agents}

Susceptibility to antimicrobial agents was determined by a disk diffusion assay as described previously ${ }^{34}$ with disks containing: penicillin G, oxacillin, streptomycin, neomycin, gentamicin, chloramphenicol, tetracycline, minocycline, erythromycin, lincomycin, sulphonamide, trimethoprim, pefloxacin, rifampicin, fusidic acid, fosfomycin, spectinomycin, and vancomycin (Diagnostics Pasteur, Marne La Coquette, France). Disks were prepared with streptogramin A $20 \mu \mathrm{g}$, streptogramin B $40 \mu \mathrm{g}$, cadmium acetate $0.2 \mu \mathrm{mol}$, mercuric nitrate $0.2 \mu \mathrm{mol}$, sodium arsenate $2 \mu \mathrm{mol}$, ethidium bromide $200 \mu \mathrm{g}$, acriflavine $200 \mu \mathrm{g}$, propamidine isethionate $200 \mu \mathrm{g}$ and cetyltrimethylammonium bromide $10 \mu \mathrm{g}$.

\section{Detection of antibiotic-inactivating enzymes}

Enzymes inactivating penicillin $G$ and streptogramins A and B were detected as described previously. ${ }^{34}$

\section{Phage-typing}

Isolates were phage-typed by the standard method of Blair and Williams ${ }^{35}$ with the international set of 23 phages used at Routine Test Dilution (RTD) and $100 \times$ RTD. Typing was also performed after incubation of bacterial cultures at $56^{\circ} \mathrm{C}$ for $2 \mathrm{~min}$.

\section{Serotyping}

Isolates were typed by slide agglutination ${ }^{38,39}$ of formalin-killed cells with 16 specific antisera (I, II, III, $6,7,9,10,14,15,16,17,18,66438,61218,64043$ and 64048).

\section{DNA isolation and analysis}

Total cellular DNA was isolated from the staphylococcal strains and purified as described previously. ${ }^{44}$

A rapid procedure ${ }^{48}$ was used to screen for plasmid DNA. A large-scale plasmid isolation technique, involving alkaline lysis ${ }^{49}$ followed by purification on a caesium chloride-ethidium bromide gradient, was also used to obtain plasmids from the staphylococcal strains isolated in France. Plasmid DNA isolated from
E. coli strains was purified by centrifugation in a caesium chloride-ethidium bromide gradient. ${ }^{50}$

The restriction endonucleases $A l u \mathrm{I}, A v a \mathrm{II}, B g l \mathrm{II}$, DraI, EcoRI, HincII, HindIII, Sau3A,ScaI, TaqI (Amersham International, Little Chalfont) and DdeI (Biolabs, New England, MA, USA) were used according to the manufacturer's instructions. Electrophoresis of digested DNA was performed in agarose (Sigma) $0.8 \% \mathrm{w} / \mathrm{v}$ gels in Tris-borate buffer as described by Sambrook et al. ${ }^{48}$ Bacteriophage $\lambda$ DNA (Biolabs, New England, MA, USA) digested by BgIII, $1-\mathrm{kb}$ DNA ladder (Bethesda Research Laboratories, Inc., Cockeysville, MD, USA) and the Raoul I ladder (Appligene, Strasbourg, France) were used as molecular size markers.

\section{Blotting and hybridisation}

DNA was transferred from agarose gels to nitrocellulose filters by the bidirectional method described by Smith and Summers. ${ }^{51}$ Plasmids pBA2, pSF815A and pIP1307 were used as probes. Purified plasmid DNA was labelled with $\left[\alpha^{32} \mathrm{P}\right] \mathrm{dCTP}(3000 \mathrm{Ci} / \mathrm{mmol}$; Amersham International) by the multiprime DNA labelling system (Amersham International) according to the manufacturer's instructions. The specific activity of the probes was $c .10^{9} \mathrm{cpm} / \mu \mathrm{g}$ of DNA. Hybridisation was done under stringent conditions as described previously. ${ }^{44}$ The blots were exposed to Fuji $\mathrm{RX}$ films at $-70^{\circ} \mathrm{C}$ with intensifying screens for $24 \mathrm{~h}$ up to several days.

\section{Comparison of hybridisation patterns (HP)}

The average similarity between any two HP was assessed by use of the coefficient of Dice, ${ }^{52}$ calculated as follows: Percentage similarity

$$
(\% \mathrm{~S})=\frac{\text { number of matching bands } \times 2}{\text { total number of bands }} \times 100
$$

\section{Results}

\section{Relevant characteristics of the MRSA strains}

Phage-type, susceptibility to 27 antimicrobial agents, plasmid content determined by the rapid procedure, and serotype were determined for the 82 MRSA isolates used in this study.

The 59 MRSA isolates originating from different geographical areas exhibited phage-types distinguishable by at least three strong reactions at $100 \times$ RTD and when the bacterial cultures were incubated for $2 \mathrm{~min}$ at $56^{\circ} \mathrm{C}$. These isolates were also distinguishable by their antimicrobial-resistance phenotypes. Therefore, they are considered to be unrelated. Although having distinct drug-resistance phenotypes, the 13 French MRSA had eight resistance markers in common (resistance to penicillin G, streptomycin, 
neomycin, tetracycline, minocycline, sulphonamides, cadmium acetate and sodium arsenate). Each of the unrelated MRSA isolates, except the French ones, could be distinguished by the plasmid(s) it harboured. In constrast, the 13 French unrelated isolates could not be differentiated on the basis of their plasmid content. One strain lacked plasmid DNA and the other 12 were divided into only three plasmid profiles. They all carried the same $22-\mathrm{kb}$ plasmid, pIP1066, ${ }^{16}$ encoding resistance to penicillin $\mathrm{G}$, cadmium acetate and sodium arsenate. Nine of these isolates had an additional cryptic plasmid, pIP $1067,{ }^{16}$ and one isolate had two other cryptic plasmids, pIP1067 and pIP1068. ${ }^{16}$ The North American isolates, when serotyped with 16 antisera, were found to belong to nine serotypes: serotypes I (five isolates), I-66438 (three isolates), I-III (three isolates), I-II (one isolate), I-III-66438 (six isolates), III (one isolate), III-66438 (one isolate), 10 (one isolate) and 14 (one isolate), whereas the 37 European isolates belonged to serotypes III (16 isolates) and 18 (21 isolates).

The 23 MRSA isolates sampled over a 3-year period in seven French hospitals (table I) were susceptible to phage 77 at RTD. When the phage was used at $100 \times$ RTD, and the bacterial cultures incubated at $56^{\circ} \mathrm{C}$ for $2 \mathrm{~min}$, susceptibility to additional phages was revealed: 29, 54, 75 and/or 84. All the phage-type 77 French MRSA isolates produced penicillinase and were resistant to 16 antimicrobial agents: streptomycin, spectinomycin, gentamicin, tetracycline, minocycline, erythromycin, lincomycin, streptogramin B, sulphonamides, rifampicin, cadmium acetate, mercuric nitrate, ethidium bromide, acriflavine, propamidine isethionate and cetyltrimethylammonium bromide. Twenty-one isolates were also resistant to pefloxacin, eight isolates were resistant to fosfomycin and four isolates were resistant to one of the following agents: chlorampenicol, trimethoprim, neomycin or sodium arsenate. These isolates could not be distinguished, on the basis of plasmid content, from the unrelated French MRSA isolates. They all harboured plasmid pIP $1066^{16}$ and nine of them also harboured plasmid pIP1067. ${ }^{16}$ The 23 isolates belonged to serotype 18 .

\section{Hybridisation patterns (HP) obtained with probe $p B A 2$}

With plasmid pBA2 as probe, nineteen different HP were observed when the cellular DNA of the 102 $S$. aureus isolates was digested with EcoRI (labelled E) and nine HP when it was digested with HindIII (labelled $\mathrm{H}$ ). No hybridisation was detected when the same cellular DNA was probed with plasmid pBR322. The schematic representation of the EcoRI and HindIII HP is shown in fig. 1. The frequency with which each pattern occurred within each group of strains is reported in table II. Sixty-six percent of the 59 unrelated MRSA isolates had the same EcoRI HP (E1) and $90 \%$ of these had the same HindIII HP (H1). Thus, despite their different geographical origins, most of the unrelated MRSA isolates displayed similarly localised rRNA sequences. In contrast, these two patterns were uncommon among the 20 unrelated MSSA strains. Even though fewer MSSA strains were studied and despite the common French source of 17 of them, the diversity of their HP was greater than that observed among the unrelated MRSA isolates.

Among the 23 phage-type 77 French MRSA isolates, five EcoRI HP and three HindIII HP could be distinguished. As observed for the unrelated isolates, hybridisation patterns E1 and $\mathrm{H} 1$ (fig. 1) were predom-

Table I. Phage-types of 23 epidemic MRSA isolates from seven French hospitals over a 3-year period (1984-1987)

\begin{tabular}{|c|c|c|c|}
\hline \multirow{2}{*}{$\begin{array}{c}\text { Hospital } \\
\text { designation, } \\
\text { city }\end{array}$} & \multirow{2}{*}{$\begin{array}{l}\text { Number of } \\
\text { strains }\end{array}$} & \multicolumn{2}{|c|}{ Phage-type* } \\
\hline & & $100 \times$ RTD & RTD \\
\hline A, Paris & $\begin{array}{l}2 \\
5\end{array}$ & $\begin{array}{l}54+77++84++ \\
54++77++84++\end{array}$ & \\
\hline $\mathrm{B}$, Paris & $\begin{array}{l}3 \\
1\end{array}$ & $\begin{array}{l}34++71++84++ \\
54+77++84++\end{array}$ & \\
\hline C, Paris & 1 & $54 t+77++84 t+$ & \\
\hline B, Paris & 3 & $77++84++$ & \\
\hline D, Toulouse & 1 & $77++84++$ & \\
\hline $\mathrm{E}$, Paris & 1 & $77++84++$ & $77++$ \\
\hline F, Nevers & 1 & $77++84++$ & or $77+$ \\
\hline A, Paris & 1 & $54++77++$ & or $77+$ \\
\hline C, Paris & 1 & $54++77++$ & \\
\hline G, Paris & 1 & $54++77++$ & \\
\hline A, Paris & 1 & $29++77++84++$ & \\
\hline F, Nevers & 1 & $\underline{29++77++\overline{84++}}$ & \\
\hline A, Paris & 1 & $54++75++77++84++$ & \\
\hline $\mathrm{C}$, Paris & 1 & $54++75++77++\overline{84++}$ & \\
\hline C, Paris & 1 & $54++\overline{75++} 77++\overline{84++}$ & $54+\underline{75+77++}$ \\
\hline
\end{tabular}

* After incubation of the bacterial cultures at $56^{\circ} \mathrm{C}$ for $2 \mathrm{~min}$. The phage reactions underlined were not detected without incubation at $56^{\circ} \mathrm{C}$.

RTD, Routine Test Dilution; $100 \times$ RTD, phage at 100 -fold higher concentration.

,$++ \geqslant 50$ plaque-forming units (pfu);,$+ 20-50 \mathrm{pfu} ; \pm<20 \mathrm{pfu}$. 


\begin{tabular}{|c|c|c|c|c|c|c|c|c|c|}
\hline \multirow{2}{*}{$\begin{array}{l}\text { Restriction } \\
\text { enzymes }\end{array}$} & \multirow{2}{*}{ HP } & \multirow{2}{*}{$\begin{array}{l}\text { Number of } \\
\text { strains }\end{array}$} & \multicolumn{7}{|c|}{ Fragment size (kb) } \\
\hline & & & 20 & 10 & & 5 & & 1 & 0.5 \\
\hline \multirow[t]{19}{*}{ EcoRI } & E1 & 56 & I & I & & | || & 11 & II & \\
\hline & E2 & 1 & 1 & 1 & 1 & II & 11 & 11 & \\
\hline & E3 & 1 & 1 & 1 & & 11 & II & II & \\
\hline & BA & 9 & 1 & 11 & & II & 11 & 11 & \\
\hline & B5 & 1 & 1 & 11 & 1 & II & II & 11 & \\
\hline & B6 & 1 & 1 & 11 & I & I & II & 11 & \\
\hline & E7 & 1 & I & $i$ & & |I II & 1 & II & \\
\hline & B8 & 3 & i & 1 & & I II & 11 & 11 & \\
\hline & Bg & 1 & 1 & 11 & & II & 11 & 11 & \\
\hline & B10 & 2 & 1 & 1 & & 1|| & II & 11 & \\
\hline & B11 & 3 & I & 1 & & II & 1 & 11 & \\
\hline & E600 & 1 & 1 & 1 & & $\|$ I & II & 11 & \\
\hline & B61 & 12 & 1 & 1 & & I II & 1 & 11 & \\
\hline & B62 & 3 & 1 & I & & 11 & II & 11 & \\
\hline & B63 & 1 & 1 & II & & II I II & 1 & II & \\
\hline & B64 & 1 & 1 & 1 & & |1 || & 11 & II & \\
\hline & 865 & 1 & I & 11 & & 11 & 11 & 11 & \\
\hline & B67 & 1 & 1 & 1 & & I II & 11 & 11 & \\
\hline & B68 & 3 & 1 & 1 & 1 & 111 & 11 & 11 & \\
\hline \multirow[t]{9}{*}{ HindIII } & H1 & 77 & & 1 & & & 1 & 1 & 11 \\
\hline & н3 & 4 & & & I & & III & I & 11 \\
\hline & $\mathrm{HA}$ & 2 & & & 1 & & 11 & 1 & 11 \\
\hline & H5 & 2 & & 1 & & & 1 & 1 & 11 \\
\hline & H6 & 1 & 1 & I & & & 1 & 1 & 11 \\
\hline & H7 & 9 & & & 1 & & 1 & I & 11 \\
\hline & нв & 3 & & & 1 & & 1 & I & 11 \\
\hline & H60 & 2 & & 1 & & & 11 & 1 & 11 \\
\hline & H61 & 2 & & & 1 & 1 & 1 & 1 & 11 \\
\hline
\end{tabular}

Fig. 1. Schematic representation of the $19 E c o$ RI and nine HindIII HP detected in the 102 S. aureus strains analysed with $\alpha^{32}$ P-labelled $\mathrm{pBA} 2$ as a probe.

inant; they occurred in 15 and 21 isolates, respectively (table II).

\section{Hybridisation patterns obtained with probe pSF815A}

In the isolates resistant to gentamicin ( 36 of the 59 unrelated MRSA isolates and all of the 23 phage-type 77 French isolates), restriction fragments that hybridised with probe pSF815A were detected on a $2.5 \mathrm{~kb}-$ HindIII fragment (results not shown) and on EcoRI fragments of various sizes (fig. 2). Fourteen distinct EcoRI HP were observed among the 36 unrelated gentamicin-resistant MRSA isolates. Twelve of these patterns consisted of a single hybridising band and the two others consisted of two bands. Each of the 23 phage-type 77 French MRSA isolates carried a single $E c o$ RI fragment of $8.5 \mathrm{~kb}$ that hybridised with probe pSF815A, as did six unrelated MRSA isolates, including three French isolates.

None of the strains which were susceptible to gentamicin (23 of the 59 unrelated MRSA isolates and the $20 \mathrm{MSSA}$ ) carried detectable nucleotide sequences that hybridised with the probe pSF815A. Moreover, as has been previously reported, ${ }^{44}$ none of the plasmids harboured by the French MRSA, pIP1066, pIP1067 and pIP1068, hybridised with this probe.

\section{Mapping of the insert carried by the probe pIP1307}

As reported previously, ${ }^{44}$ plasmid pIP1307 consists of pBR322 containing a $2 \cdot 1-\mathrm{kb}$ HindIII insert carrying the gene $a a c \mathrm{~A}-a p h \mathrm{D}$ isolated from the chromosomal DNA of a French MRSA isolate. The recognition sites for the restriction enzymes AluI, AvaII, DdeI, DraI, HincII, Sau3A, ScaI and TaqI were mapped in the $2 \cdot 1-\mathrm{kb}$ insert of plasmid pIP1307 and the map was compared to that of $\operatorname{Tn} 4001,{ }^{53,54}$ deduced from the corresponding nucleotide sequence. This comparison suggested that the $2 \cdot 1-\mathrm{kb}$ insert of plasmid pIP1307 was derived from the internal $2 \cdot 5-\mathrm{kb}$ HindIII fragment of Tn 4001 by a deletion of $0.4 \mathrm{~kb}$. This deletion was located between the initiation codon of the gene aacA$a p h \mathrm{D}$ (nt 700) and the AvaII site (nt 193) upstream from this codon. Thus, the $2 \cdot 1-\mathrm{kb}$ insert contained the aacA-aphD gene and at least one intact copy of the 297-bp sequence of IS256 located within the internal HindIII fragment of Tn4001, downstream from the resistance gene. ${ }^{44}$ 
Table II. EcoRI and HindIII hybridisation patterns (HP) of cellular DNA of $102 \mathrm{~S}$. aureus strains probed with pBA2

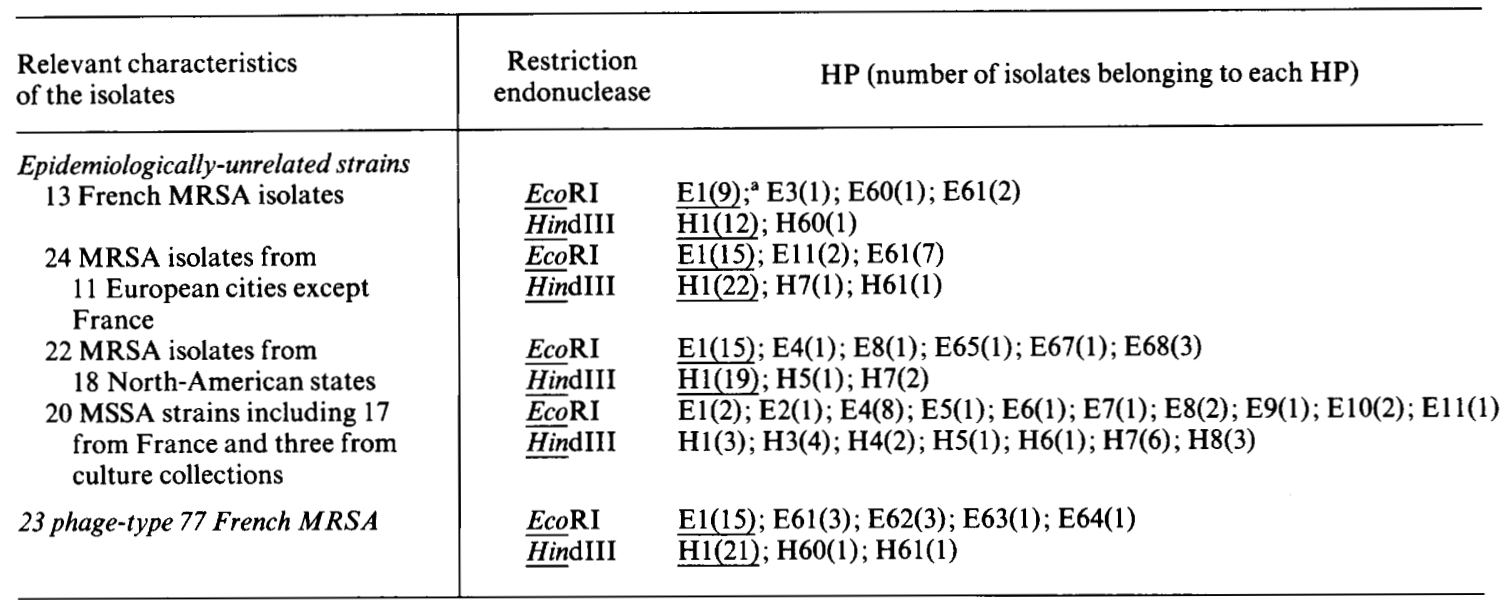

a The hybridisation patterns underlined were predominant, accounting for $>62 \%$ of the isolates analysed.

\section{Hybridisation patterns obtained with probe pIP1307}

None of the strains which were susceptible to gentamicin carried nucleotide sequences detectable by hybridisation with plasmid pIP1307. In each of the gentamicin-resistant MRSA isolates, the nucleotide sequences hybridising with plasmid pIP1307 were located on one of the 12 EcoRI fragments and on 1-14 $H$ indIII fragments. At least two unrelated hybridisation experiments were done to ensure that the HP is reproducible. The schematic representation of the 42 $E c o$ RI HP detected in the 59 gentamicin-resistant MRSA isolates analysed including 36 unrelated MRSA is shown in fig. 2. The EcoRI HP of 20 French MRSA isolates are shown in fig. 3. Among the 36 unrelated MRSA isolates studied, 32 EcoRI HP (fig. 2, HP 11-42) and 28 HindIII HP (results not shown) were detected. Each of the unrelated MRSA isolates carrying more than one EcoRI or HindIII fragment and hybridising with plasmid pIP1307 was characterised by its own EcoRI HP or HindIII HP.

In the 23 phage-type 77 French MRSA isolates, 10 EcoRI HP were detected (fig. 2, HP 1-10; fig. 3, HP 1-10). These patterns consisted of 8-12 EcoRI fragments hybridising with plasmid pIP1307, of which seven were common to all the HP. Seven HindIII HP were observed in the cellular DNA of these isolates (results not shown). Each HindIII HP consisted of 1114 bands, of which nine were common to all the HP.

The EcoRI HP (fig. 2) were compared within that of each group of MRSA isolates and the Dice coefficient $^{52}$ was calculated. The extreme values observed were $66 \cdot 6-100 \%$ for the 23 phage-type 77 French isolates, $0-37 \cdot 1 \%$ for the 10 unrelated French isolates, $0-36 \cdot 3 \%$ for the 13 unrelated isolates from European cities outside of France, and $0-100 \%$ for the 13 unrelated North American isolates. The value obtained with the latter isolates was $100 \%$ because five of them had the same EcoRI HP pattern consisting of a single hybridising band. The extreme values for the unrelated North American MRSA isolates could be recalculated by counting these five isolates as one; in this case, there were 13 distinct EcoRI HP and the extreme values were $0-50 \%$.

Each of the EcoRI HP obtained for the phage-type 77 French MRSA isolates was compared with each of the EcoRI HP detected among the unrelated MRSA isolates (fig. 2). The extreme values observed were 0 $58.8 \%$ with the 10 unrelated French isolates, $0-45.4 \%$ with the 13 unrelated European isolates except the French ones and $0-37 \cdot 5 \%$ with the 13 unrelated North American isolates.

\section{Discussion}

The usefulness of three DNA probes for typing MRSA isolates and tracing epidemic MRSA strains widespread in French hospitals was evaluated in this study by analysing the HP obtained with these probes. $E c o$ RI and $H$ indIII-digested cellular DNA of unrelated MRSA isolates from different sources (Europe and North America), and of French MRSA isolates having identical or similar phage-types and numerous resistance markers in common were examined.

By the use of probe $\mathrm{pBA} 2^{42}$ it was possible to detect re-arrangements occurring in the rRNA gene clusters or in the adjacent chromosomal sequences. In addition to its utility for species identification, this probe revealed diversity in patterns within most of the staphylococcal species investigated. ${ }^{55}$ In this study, we showed that most of the MRSA isolates, whatever their sources, had the same EcoRI or HindIII HP. The most frequent patterns in the MRSA strains, E1 and $\mathrm{H}$ 1, were shown to be uncommon among the MSSA isolates. These results suggested that many MRSA isolates may have evolved recently from a single ancestral strain, a hypothesis that has already been proposed for the MRSA strains isolated in Europe. ${ }^{56}$ The number of patterns obtained with EcoRI-digested 


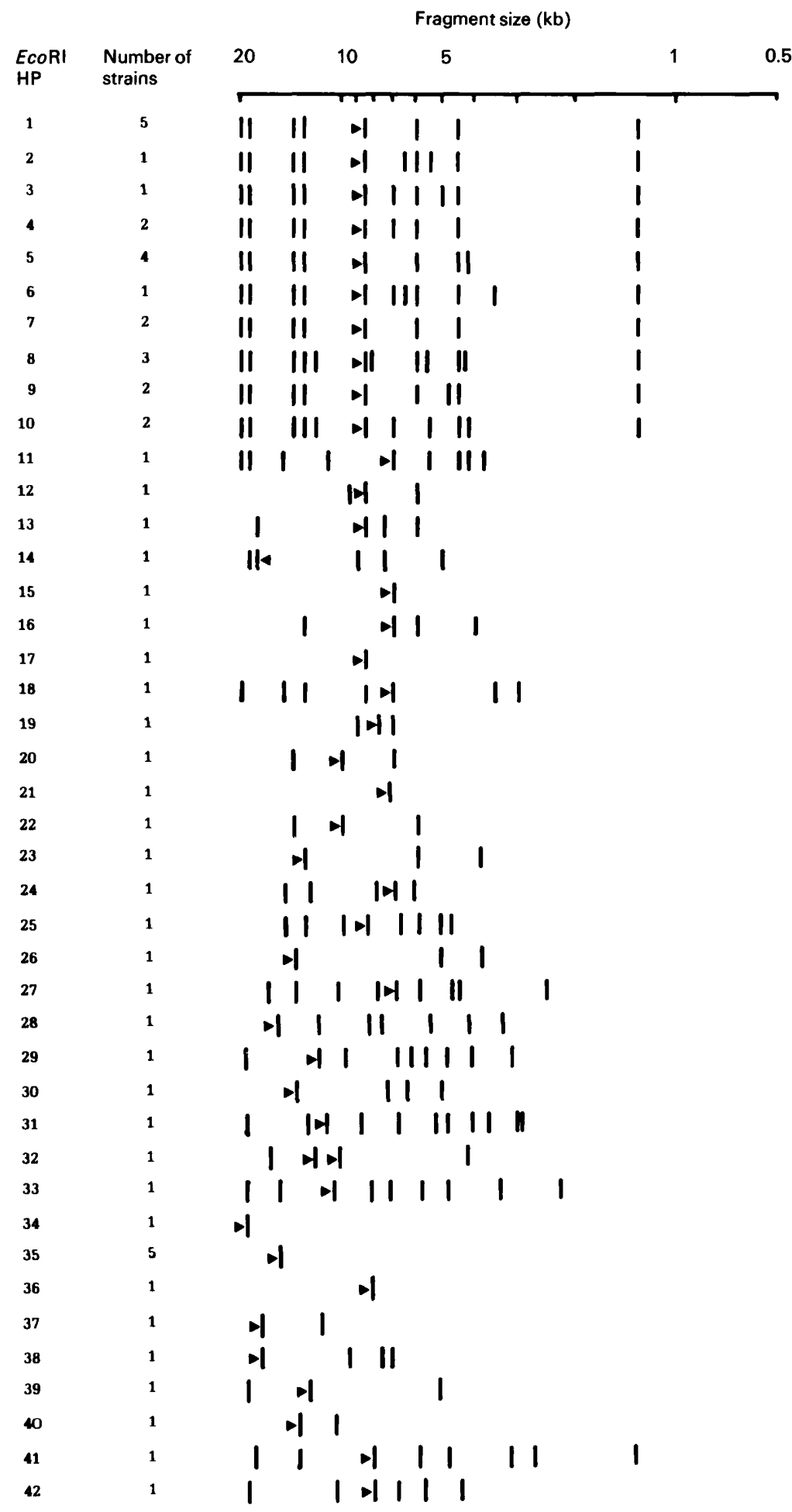

Fig. 2. Schematic representation of 42 EcoRI HP detected among 59 gentamicin-resistant MRSA isolates with $\alpha^{32}$ P-labelled pIPI307 as a probe. The bands marked with an arrow are those which also hybridised with probe pSF815A. HP 1-10 were obtained with the 23 phagetype 77 French isolates, HP 11-20 with the 10 French unrelated isolates, 21-33 with the 13 unrelated isolates from European cities outside France and 34-42 with the 13 North-American unrelated isolates.

DNA was greater than that obtained with HindIIIdigested DNA. Therefore, the use of EcoRI instead of $H$ indIII to digest cellular DNA is recommended for typing $S$. aureus isolates. However, only isolates having patterns other than $\mathrm{El}$ or $\mathrm{H} 1$ could be accurately differentiated with probe pBA2.

A greater diversity in patterns was observed with the two other probes, pSF815A $\mathrm{A}^{43}$ and pIP1307. ${ }^{44}$
These two probes, which carry the gene aacA-aphD, could be used only for typing gentamicin-resistant isolates. The gene $a a c \mathrm{~A}-a p h \mathrm{D}$ was located on a $2 \cdot 5-\mathrm{kb}$ HindIII fragment indicating that these isolates may carry genetic element(s) identical or similar to the staphylococcal transposons, $\operatorname{Tn} 4001^{53,54}$ or $\operatorname{Tn} 4031,{ }^{57}$ in which the aacA-aphD gene is situated on an internal 2-5-kb HindIII fragment. A single EcoRI restriction 

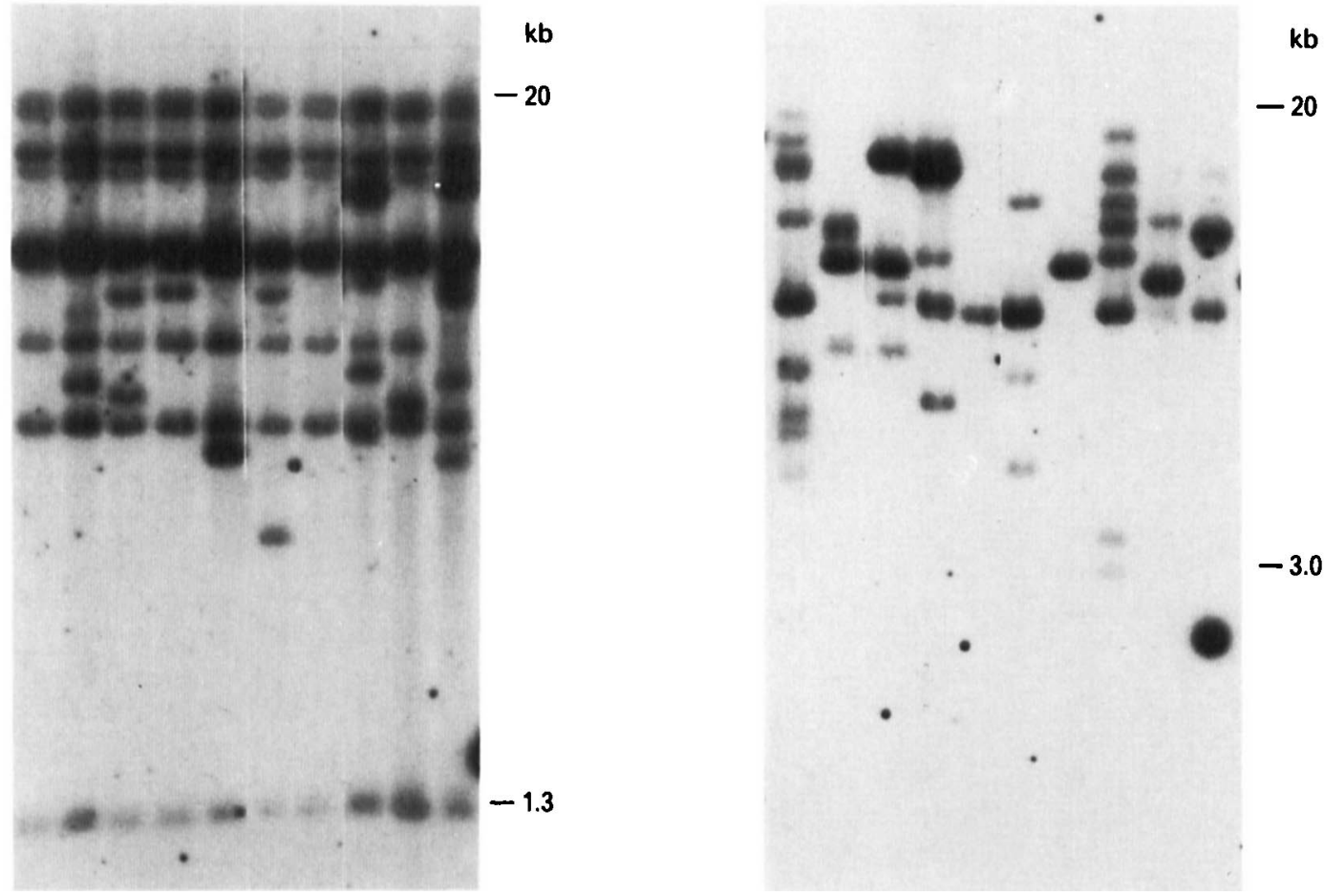

Fig. 3. Autoradiogram of EcoRI-digested cellular DNA of 20 French MRSA isolates separated by electrophoresis and probed with $\alpha^{32}$ Plabelled plasmid pIP1307. HP 1-10 were obtained with 10 phage-type 77 isolates and HP 11-20 with 10 unrelated isolates. The schematic representation of these HP is shown in fig. 2.

fragment hybridising with probe pSF815A, detected in 34 of the 36 unrelated MRSA isolates, suggests that a single copy of the gene aacA-aphD is present in these isolates. In most of the isolates, several EcoRI or $H$ indIII hybridising fragments were detected with the probe pIP1307, which contain part of IS256 in addition to the gene $a a c \mathrm{~A}-a p h \mathrm{D}$. Those fragments hybridising with probe pIP1307 but not with the aacA-aphD gene, probably carry sequences homologous to IS256. Further studies are needed to characterise the sequence hybridising with IS256 which were detected in gentamicin-resistant isolates but not in any of the gentamicin-susceptible isolates tested. It was easy to fingerprint the strains with the pIP1307 probe because numerous bands appeared in most of the HP. The diversity of patterns obtained with probe pIP1307 was much greater than that observed with probe pSF815A. With probe pIP1307, each of the unrelated isolates was characterised by its own HP, provided that the HP consisted of more than one band. The highest percentage of similarity detected among these latter HP was 50. Thus, the detection of isolates with identical HP consisting of more than one band or with HP sharing percentages of similarity higher than 50 would be good evidence that the strains were closely related. The hypothesis that isolates are closely related becomes more likely to be correct at the higher percentages of similarity.

The use of probe pIP1307, was the most effective for discriminating the phage-type 77 isolates from the epidemiologically unrelated MRSA isolates. With probe pSF815A, a single $E c o$ RI fragment of $8 \cdot 5 \mathrm{~kb}$ was detected in all the phage-type 77 isolates. However, since a fragment of the same size was also detected in six of the 36 gentamicin-resistant unrelated MRSA isolates studied, the use of this probe alone is not enough to trace precisely the dissemination of phage-type 77 French MRSA isolates. In contrast, since the same seven EcoRI and nine HindIII fragments hybridising with the probe pIP1307 were detected in all phage-type 77 isolates, the use of this probe alone sufficed to trace the epidemic phage-type 77 strains widespread in the French hospitals. This typing method was particularly useful for epidemic isolates giving weak lytic reactions. However, if the isolates lack common bands, no conclusion concerning their relatedness can be formulated, because a single molecular re-arrangement occurring in an epidemic strain may cause a large modification of the HP. If such modifications take place, then the use of this probe will be limited.

The best typing methods are those by which one or more characteristics not commonly found in epidemiologically unrelated isolates can be detected. In epidemiological surveys, the presence of such characteristics in many strains studied suggests a close relatedness. Several methods are often required to detect uncommon markers to which we attribute a particular weight. To avoid applying numerous methods at the same time, we use successively the following techniques, reported here in decreasing order of priority, until we detect at least one such marker: drug 
resistance phenotyping, phage-typing, hybridisation of EcoRI-digested cellular DNA with probes pIP1307 and $\mathrm{pBA} 2$ and plasmid content analysis. To establish the order of priority, we have taken into account the power of the methods in discriminating the French MRSA isolates as well as the convenience of the techniques and cost. Since North American isolates appear to display more diverse serotypes and plasmid

\section{References}

1. Bigelow N, Ng LK, Robson HG, Dillon JR. Strategies for molecular characterisation of methicillin- and gentamicinresistant Staphylococcus aureus in a Canadian nosocomial outbreak. J Med Microbiol 1989; 30: 51-58.

2. Bouvet A, Fournier JM, Audurier A, Branger C, Orsoni A, Girard C. Epidemiological markers for epidemic strain and carrier isolates in an outbreak of nosocomial oxacillinresistant Staphylococcus aureus. J Clin Microbiol 1990; 28 : 1338-1341.

3. Bradley JM, Noone P, Townsend DE, Grubb WB. Methicillinresistant Staphylococcus aureus in a London hospital. Lancet $1985 ; 1$ : 1493-1495.

4. Carroll JD, Pomeroy HM, Russell RJ et al. A new methicillinand gentamicin-resistant Staphylococcus aureus in Dublin: molecular genetic analysis. J Med Microbiol 1989; 28: 1523.

5. Cookson BD, Phillips I. Epidemic methicillin-resistant Staphylococcus aureus. J Antimicrob Chemother 1988; 21 Suppl. C: 57-65.

6. Gillespie MT, Lyon BR, Skurray RA. Typing of methicillinresistant Staphylococcus aureus by antibiotic resistance phenotypes. J Med Microbiol 1990; 31: 57-64.

7. Khalifa KI, Heiba AA, Hancock G. Nontypable bacteriophage patterns of methicillin-resistant Staphylococcus aureus involved in a hospital outbreak. J Clin Microbiol 1989; 27: 2249-2251

8. Law MR, Gill ON. Hospital-acquired infection with methicillin-resistant and methicillin-sensitive staphylococci. Epidemiol Infect 1988; 101 : 623-629.

9. Maple PAC, Hamilton-Miller JMT, Brumfitt W. World-wide antibiotic resistance in methicillin-resistant staphylococcus aureus. Lancet $1989 ; 1: 537-540$

10. Mel Christino JAG, Torres-Pereirea A. Methicillin-resistant Staphylococcus aureus: a 6-month survey in a Lisbon paediatric hospital. J Hyg 1986; 97 : 265-272.

I1. Pavillard R, Harvey K, Douglas D et al. Epidemic hospitalacquired infection due to methicillin resistant Staphylococcus aureus in major Victorian hospitals. Med J Austral $1982 ; 1: 451-454$

12. Skurray RA, Rouch DA, Lyon BR et al. Multiresistant Staphylococcus aureus: genetics and evolution of epidemic Australian strains. J Antimicrob Chemother 1988; 21 Suppl C: $19-38$

13. Trallero EP, Arenzana JMG, Eguiluz GC, Cáncer RC. Prevalence of methicillin-resistant Staphylococcus aureus in a Spanish hospital. Rev Infect Dis 1988; 10: 627-628.

14. Witte W, Braulke Ch. Multiply- and methicillin-resistant Staphylococcus aureus strains isolated in the German Democratic Republic in 1985 and 1986. Epidemiol Infect 1987; 99: 603-612.

15. Archer GL, Mayhall CG. Comparison of epidemiological markers used in the investigation of an outbreak of methicillin-resistant Staphylococcus aureus infections. $J$ Clin Microbiol 1983; 18: 395-399.

16. El Solh N, Fouace JM, Pillet J, Chabbert YA. Plasmid DNA content of multiresistant Staphylococcus aureus strains. Ann Microbiol (Paris) 1981; 132B: 131-156.

17. El Solh N, Fouace JM, Shalita Z, Bouanchaud DH, Novick RP, Chabbert YA. Epidemiological and structural studies of Staphylococcus aureus $\mathbf{R}$ plasmids mediating resistance to tobramycin and streptogramin. Plasmid 1980; 4: 117120 .

18. Hartstein AI, Morthland VH, Eng S, Archer GL, Schoenknecht FD, Rashad AL. Restriction enzyme analysis of plasmid DNA and bacteriophage typing of paired Staphylococcus profiles than the French MRSA isolates, a greater priority may be attributed to these methods for typing the former isolates. An exchange of information with epidemiologists is required to facilitate the task of the microbiologists in epidemiological surveys.

We thank Théa Horaud for criticism of the manuscript and Odette Rouelland for secretarial assistance.

aureus blood culture isolates. J Clin Microbiol 1989; 27 : 1874-1879.

19. Kozarsky PE, Rimland D, Terey PM, Wachsmuth K. Plasmid analysis of simultaneous nosocomial outbreaks of methicillin-resistant Staphylococcus aureus. Infect Control 1986; 7 : 577-581

20. Lyon BR, May JW, Skurray RA. Analysis of plasmids in nosocomial strains of multiple-antibiotic-resistant Staphylococcus aureus. Antimicrob Agents Chemother 1983; 23: $817-826$.

21. Witte W, Marples RR, Richardson JF. Complex typing of methicillin-resistant Staphylococcus aureus (MRSA). Zentralbl Bakteriol Mikrobiol Hyg [A] 1988; 270: 76-82.

22. Zuccarelli AJ, Roy I, Harding GP, Couperus JJ. Diversity and stability of restriction enzyme profiles of plasmid DNA from methicillin-resistant Staphylococcus aureus. J Clin Microbiol 1990; 28: 97-102.

23. Burnie JP, Matthews RC, Lee W, Murdoch D. A comparison of immunoblot and DNA restriction patterns in characterising methicillin-resistant isolates of Staphylococcus aureus. J Med Microbiol 1989; 29: 255-261.

24. Coia JE, Thomson-Carter F, Baird D, Platt DJ. Characterisation of methicillin-resistant Staphylococcus aureus by biotyping, immunoblotting and restriction enzyme fragmentation patterns. $J$ Med Microbiol $1990 ; 31$ : 125-132.

25. Goering RV, Duensing TD. Rapid field inversion gel electrophoresis in combination with an rRNA gene probe in the epidemiological evaluation of staphylococci. J Clin Microbiol $1990 ; 28: 426-429$.

26. Hall LMC, Jordens JZ, Wang F. Methicillin-resistant Staphylococcus aureus from China characterized by digestion of total DNA with restriction enzymes. Epidemiol Infect 1989; 103: 183-192.

27. Jordens JZ, Hall LMC. Characterisation of methicillin-resistant Staphylococcus aureus isolates by restriction endonuclease digestion of chromosomal DNA. J Med Microbiol 1988; 27: 117-123.

28. Clink J, Pennington TH. Staphylococcal whole-cell polypeptide analysis: evaluation as a taxonomic and typing tool. $J \mathrm{Med}$ Microbiol 1987; 23 : 41-44.

29. Gaston MA, Duff PS, Naidoo J et al. Evaluation of electrophoretic methods for typing methicillin-resistant Staphylococcus aureus. J Med Microbiol 1988; 26: 189-197.

30. Stephenson JR, Crook SJ, Tabaqchali S. New method for typing Staphylococcus aureus resistant to methicillin based on sulphur ${ }^{-35}$ methionine labelled proteins; its application in an outbreak. Br Med J 1986; 293 : 581-583.

31. Thomson-Carter FM, Pennington TH. Characterisation of methicillin-resistant isolates of Staphylococcus aureus by analysis of whole-cell and exported proteins. $J$ Med Microbiol 1989; 28 : 25-32.

32. Mulligan ME, Kwork RYY, Citron DM, John JFJ, Smith PB Immunoblots, antimicrobial resistance, and bacteriophage typing of oxacillin-resistant Staphylococcus aureus. J Clin Microbiol 1988; 26: 2395-2401.

33. Branger C, Goullet P. Esterase electrophoretic polymorphism of methicillin-sensitive and methicillin-resistant strains of Staphylococcus aureus. J Med Microbiol 1987; 24: 275-281.

34. El Solh N, Bismuth R, Allignet J, Fouace JM. Résistance à la pristinamycine (ou virginiamycine) des souches de Staphylococcus aureus. Pathol Biol 1984; 32: 362-368.

35. Blair JE, Williams, REO. Phage typing of staphylococci. Bull WHO $1961 ; 24: 771-784$

36. Richardson JF, Chittasobhon N, Marples RR. Supplementary phages for the investigation of strains of methicillinresistant Staphylococcus aureus. J Med Microbiol 1988; 25 . 67-74. 
37. Chabbert YA, Pillet J. Correlation between "methicillin resistance" and serotype in Staphylococcus. Nature 1967; 213: 1137.

38. Pillet J, Orta B. Etude sérologique de souches de Staphylococcus aureus d'origine aviaire. Mise en évidence de deux nouveaux sérotypes. Ann Microbiol 1973; 124A : 207-214.

39. Pillet J, Orta B, Corrieras F. Sérotypie des staphylocoques. Intérêt d'une réduction du nombre des souches types utilisées. Ann Inst Pasteur 1967; 113: 363-374.

40. Branger C, Goullet $P$, Boutonnier A, Fournier JM. Correlation between esterase electrophoretic types and capsular polysaccharide types 5 and 8 among methicillin-susceptible and methicillin-resistant strains of Staphylococcus aureus. $J$ Clin Microbiol 1990; 28 : 150-151.

41. El Solh N, Fouace JM. Caractéristiques des souches résistantes aux bêta-lactamines isolées en France. In: Vachon F. Régnier B (eds) Problèmes actuels de pathologie infectieuse et de réanimation. Les infections à staphylocoques méticilline résistants Paris, Librairie Arnette. 1984: 27-49.

42. Iglesias A, Ceglowski P, Trautner TA. Plasmid transformation in Bacillus subtilis. Effects of the insertion of Bacillus subtilis rRNA genes into plasmids. Mol Gen Genet 1983; 192: 149155.

43. Ferretti JJ, Gilmore KS, Courvalin P. Nucleotide sequence analysis of the gene specifying the bifunctional 6'aminoglycoside acetyltransferase 2 "-aminoglycoside phosphotransferase enzyme in Streptococcus faecalis and identification and cloning of gene regions specifying the two activities. J Bacteriol 1986; 167: 631-638.

44. El Solh N, Moreau N, Ehrlich SD. Molecular cloning and analysis of Staphylococcus aureus chromosomal aminoglycoside resistance genes. Plasmid 1986; 15: 104-118.

45. Novick RP. Properties of cryptic high-frequency transducing phage in Staphylococcus aureus. Virology 1967; 33: 155166.

46. Dagert M, Ehrlich SD. Prolonged incubation in calcium chloride improves the competence of Escherichia coli cells. Gene $1979 ; 6: 23-28$.
47. Sutcliffe JC. pBR322 restriction map derived from the DNA sequence: accurate DNA size markers up to 4361 nucleotide pairs long. Nucleic Acids Res 1978; 5: 2721-2728.

48. Kado CI, Liu S-T. Rapid procedure for detection and isolation of large and small plasmids. $J$ Bacteriol 1981 ; 145: 1365 1371.

49. El Solh N, Allignet J, Bismuth R, Buret B, Fouace J-M Conjugative transfer of staphylococcal antibiotic resistance markers in the absence of detectable plasmid DNA. Antimicrob Agents Chemother 1986; 30: 161-169.

50. Sambrook J, Fritsch EF, Maniatis T. Molecular cloning: a laboratory manual, 2nd edn. Cold Spring Harbour, NY, Cold Spring Harbor Laboratory Press. 1989: Book 1.

51. Smith GE, Summers MD. The bidirectional transfer of DNA and RNA to nitrocellulose or diazobenzyloxymethyl-paper. Anal Biochem 1980; 109 : 123-129.

52. Dice LR. Measures of the amount of ecological association between species. Ecology 1945; 26: 297-302.

53. Byrne ME, Rouch DA, Skurray RA. Nucleotide sequence analysis of IS256 from the Staphylococcus aureus gentamicin-tobramycin-kanamycin-resistance transposon Tn 4001 Gene $1989 ; 81$ : 361-367.

54. Rouch DA, Byrne ME, Kong YC, Skurray RA. The aacA-aphD gentamicin and kanamycin resistance determinant of Tn4001 from Staphylococcus aureus: expression and nucleotide sequence analysis. J Gen Microbiol 1987; 133: 30393052.

55. De Buyser M-L, Morvan A, Grimont F, El Solh N. Characterization of Staphylococcus species by ribosomal RNA gene restriction patterns. J Gen Microbiol 1989; 135: 989-999.

56. Lacey RW. Antibiotic resistance plasmids of Staphylococcus aureus and their clinical importance. Bacteriol Rev 1975; 39: 1-32.

57. Thomas WD, Archer GL. Mobility of gentamicin resistance genes from staphylococci isolated in the United States: identification of $\mathrm{Tn} 4031$, a gentamicin resistance transposon from Staphylococcus epidermidis. Antimicrob Agents Chemother 1989 ; 33 : 1335-1341. 